\title{
TEORIA POLÍTICA CONTEMPORÂNEA, PLURALIDADE E PLURALISMO: UM DEBATE*
}

\author{
Raquel Kritsch \\ é Doutora pela Universidade de São Paulo e Professora-Pesquisadora do Departamento e \\ Programa de Mestrado em Ciências Sociais da Universidade Estadual de Londrina (UEL). \\ Londrina,PR.Brasil.E-mail:<kritsch@uel.brl> \\ Raissa W. Ventura \\ é Doutoranda em Ciência Política pela Universidade de São Paulo (USP). \\ São Paulo, SP. Brasil.E-mail: <raissa.wventura@gmail.com> \\ http://dx.doi.org/10.1590/0102-015055/102
}

As preocupações que nortearam este dossiê nasceram da mesa-redonda organizada por Bernardo Ferreira e Raquel Kritsch para a edição de 2016 do X Encontro da ABCP, intitulada Caminhos da teoria política: normatividade, institucionalidade, empiria e história em debate. A constatação era a de que discutir a natureza da produção de conhecimento na área da teoria política, a partir dos vários modos pelos quais a disciplina foi - e continua sendo - praticada desde o século $\mathrm{XX}^{1}$ poderia constituir empresa relevante e frutífera para nossa área disciplinar. Ponto de partida para o debate foi a análise feita por A. Vincent (2004, p. 19) em The nature of political theory a respeito do que entende como cinco concepções ou elementos da teoria política, cada qual apresentando fundamento próprio, que teriam demarcado o terreno

\footnotetext{
* Agradecemos aos membros do Getepol (Grupo de Estudos em Teoria Política$\mathrm{CNPq}$ ) pelas observações críticas e pelos debates sobre as questões abordadas nesta apresentação, bem como a Lucas Petroni, parceiro verdadeiramente engajado no diálogo, que muito nos ajudou a enriquecer algumas de nossas posições. Embora tais interlocuções tenham sido fundamentais para as ideias esboçadas, todas as escolhas e decisões analíticas aqui tomadas são de nossa inteira e exclusiva responsabilidade. Este trabalho recebeu financiamento do CNPq (163953/2014-7) e da Capes-PDSE (88881.131577/2016-01).

${ }^{1}$ Cf. $<$ https://goo.gl/5uQZu7>.
} 
da disciplina bem como a percepção de sua natureza no século XX, a saber, as concepções normativa clássica, institucional, histórica, empírica e ideológica. Participaram do debate Alessandro Pinzani, Ricardo V. Silva, Andrei Koerner e Flávia Biroli.

$\mathrm{O}$ interesse suscitado pela proposta e a proficuidade da discussão deram origem a outras iniciativas similares, entre as quais merece menção a mesa-redonda ocorrida no encontro da Anpocs (2017), intitulada Ciência política e teoria política: fundações, questões, tensões, (des)caminhos, ${ }^{2}$ que teve como objetivo aprofundar o debate lançado um ano antes, agora com foco na questão da especificidade da teoria política - e seu entrecruzamento e/ou sobreposições com outras práticas e campos disciplinares, como a filosofia política e a história do pensamento político - bem como sua relação com a ciência política. Tornaram possível esta mesa os colegas Rúrion S. Melo, Daniel de Mendonça e Ricardo V. Silva, que brindaram o público com posições e debates instigantes. Tais iniciativas terminaram por se materializar neste dossiê, que ora é apresentado para escrutínio do grande público e das(os) leitora(es) de Lua Nova, com o objetivo de ampliar as discussões a respeito da teoria política, de sua suposta natureza e/ou fundações, seus fazeres e outras questões disputadas.

\section{Multiplicidade, diversidade e polifonia}

Por detrás de tais iniciativas estiveram inquietações de naturezas diversas, ligadas pela preocupação de pensar a especificidade da produção em teoria política entre nós hoje. Contextualizar as preocupações e interrogações que deram origem aos problemas e posições abordados neste dossiê talvez seja o melhor caminho para explicar as intenções que o circundam. A constatação inicial da qual

${ }^{2}$ Cf. <https://goo.gl/HKqZGs $>$. 
partimos anos atrás, e que nos impulsionou a propor os temas aqui debatidos, era a de que a teoria política, como área de estudo e de produção de conhecimento, havia experimentado no Brasil grande crescimento. Desde os primeiros passos nesta direção, três décadas se passaram e o que havia começado como projetos modestos de alguns grupos de intelectuais interessados em engrossar as fileiras da teoria política entre nós tornou-se uma autêntica especialidade, ${ }^{3}$ com espaço institucional em departamentos de ciência política e/ou de ciências sociais, em eventos de área e associações profissionais, com financiamentos para pesquisa por parte de agências de fomento e bolsas de estudo.

Quando se avalia esse desenvolvimento à luz das experiências que tiveram lugar em outros contextos sociais, políticos, culturais e econômicos, o que se nota é que, se a produção brasileira não acompanhou a pujança de recursos, inclusive humanos, de suas congêneres situadas alhures na geopolítica do conhecimento, a qualidade do trabalho aqui desenvolvido acompanhou em boa medida o que acontecia nos mais renomados centros de pesquisa europeus e americanos: ${ }^{4}$ também entre nós a produção em teoria política especializou-se, ramificou-se e, como em outras partes, passou a contar internamente com disputas em torno dos modos de abordá-la e fundamentá-la, sejam eles histórico,

\footnotetext{
3 Tal impulso acentuou-se, sobretudo, a partir dos anos 1980-1990, quando tiveram lugar as primeiras iniciativas na direção da consolidação de núcleos de reflexão e produção em teoria política, dos quais o Programa de Pós-Graduação em Sociologia e Ciência Política do IUPERJ-UCAM (hoje, IESP-UERJ) e o Núcleo de Teoria Política do IEA-USP, que reunia pesquisadoras(es) da USP, Unicamp, Unesp e PUC-SP, constituíam talvez, naquele momento, os mais significativos e de maior visibilidade.

${ }^{4}$ Embora haja alguns estudos iniciais nesta direção, a reconstrução detalhada dos meandros desta trajetória no Brasil ainda precisa ser mapeada e, apesar de sua importância, não constitui o objeto de nossa reflexão aqui. Para um texto que caminha nessa direção, embora concentre-se apenas em anos recentes e exclusivamente no que ali é chamado de teoria política normativa, cf. Araújo e Assumpção, 2010 .
} 
empírico ou normativo. ${ }^{5}$ Em um momento em que a área de teoria política apresenta boa capacidade de (re)produção e relativa maturidade, parece-nos fundamental refletir sobre os dilemas e problemas que aquelas e aqueles que operam com e a disciplina vêm localizando em seus contextos específicos de enunciação. Tal reflexão é relevante, inclusive, para que sejamos capazes de pensar nossos próprios caminhos, em diálogo informado com a produção internacional, ${ }^{6}$ mas incluindo e/ou chamando atenção para desenvolvimentos e categorias nativas, respeitando o modo de constituição da área entre nós e nossa capacidade de fazer uso da imaginação sociológica para repensar os termos e vocabulários que constituem as teorias políticas contemporâneas e para inová-los.

Se há um ponto sobre o qual a bibliografia que se dedicou a produzir diagnósticos e a pensar metateoricamente o campo concorda quase em uníssono - coisa rara quando se trata de fazer afirmações a respeito da teoria política! - é o diagnóstico da diversidade. Andrew Vincent (2004, p. 9), por exemplo, dedica um livro inteiro à tarefa de mostrar que a política, e por extensão a teoria que investiga essa modalidade de ação, "é o lugar de uma multiplicidade de vocabulários”, o que, acrescentamos, a torna também polifônica. ${ }^{7}$ Para abordar a diversidade de autores e obras que caracterizariam o universo da teoria política, ele elege um

\footnotetext{
${ }^{5}$ Para aprofundamento do desenvolvimento da teoria política no século XX e suas ramificações internas, conferir o competente resumo destes modos de abordar teoria política em R. Silva; 2008a.

${ }_{6}$ Para tais problematizações em outras partes, cf. Frank e Tambornino, 2000; White e Moon, 2004; Leopold e Stears, 2008; Sembou, 2013; Wolin, 1969 e 2000; Nelson, 1983; Warren, 1989; Barry, 1998; Ball, 1995; 2004; Gunnell, 1993; 2011; Waldron, 2016.

7 Esse desdobramento, embora não literal na formulação de Vincent, pode ser sustentado sem grandes dificuldades a partir da ideia de que "vocabulários" constituem a codificação de um conjunto de termos ou palavras, oriundas, por sua vez, de um conjunto de sons que, quando são múltiplos, podem ser ditos polifônicos.
} 
conceito central, o de fundação ${ }^{8}$ [foundations], como guia e ideia unificadora de sua reconstrução das - contestáveis e contestadas - bases fundacionais da teoria política - a qual entende como disciplina recente - no contexto europeu e anglo-americano, desde suas origens no século XIX até a virada do milênio (cf. Vincent, 2004, pp. 11-12).

Seu intuito é procurar responder à questão: "o que pensamos que estamos fazendo quando praticamos teoria política?" (Vincent, 2004, p. 1). As respostas por ele encontradas são, como não poderia deixar de ser, múltiplas; ainda assim, o autor propõe ordená-las indicando três sentidos - que devem ser entendidos como tipos-ideais (Vincent, 2004, p. 3) - dos usos do fundacionalismo na teoria política do século $\mathrm{XX}$ : o abrangente (ou compreensivo), mais rico, próximo da "metafísica", que implica uma teoria transcendental, perfeccionista e compreensiva que compreende alguma forma de padrão objetivo do julgamento moral (Vincent, 2004, p. 3); o imanente, mais estreito, que prevê o acesso a uma fundação universal por meio de determinados conceitos que contêm os recursos para sua presença e justificação universal, o que pode ser alcançado pela reconstrução que demonstra tais justificações internas ou imanentes (Vincent, 2004, p. 4); e o do uso lógico, que recorre à prioridade lógica na ordenação das asserções e parte da ideia de que o argumento racional exige uma estrutura formal para a qual certos tipos de afirmações são fundamentais: todo pensar humano tem algum

\footnotetext{
${ }^{8}$ Vincent (2004, p. 3, nossa tradução) concebe o termo foundations em sentido amplo, mas procura delimitar seu significado nos seguintes termos: "O termo 'fundação' é usado em um sentido muito amplo. É tomado para indicar alguns tipos de asserções ou proposições, que são favorecidas de maneira absoluta sobre outras. Para ser fundacional, esta classe de asserções é vista como 'fundamental' - 'fundamental' indicando que seus possuidores não podem evitar protelar ou referir-se a ela. Esta classe de asserções está, em outras palavras, sempre pressuposta por uma diversidade de outras afirmações. [...] Asserções fundacionais também permitem que se faça inferências e deduções sistemáticas, as quais explicam e são responsáveis por uma série de outras asserções. Asserções fundacionais, portanto, têm uma capacidade abrangente. Elas asseguram a 'coerência' global de uma série de outras afirmações. Este conjunto coerente de asserções interligadas constitui uma teoria.”
} 
ponto de partida fundacional que cabe à teoria elucidar (Vincent, 2004, p. 6).

Para Vincent, então, seria possível distribuir as teorias políticas produzidas desde meados do século XIX ao longo destes três eixos ordenadores - tarefa à qual dedica a maior parte do livro. Seu objetivo explícito é "desafiar os caminhos atuais [sic] nos quais pensamos sobre e praticamos a teoria política" (Vincent, 2004, p. 10). Não cabe aqui discutir se o autor é ou não bem-sucedido nessa empreitada. Mais útil para os nossos propósitos é acompanhar sua apresentação a respeito dos modos - que ele deseja desafiar - como a teoria política, enquanto prática disciplinar autoconsciente (cf. Vincent, 2004, p. 12), tem sido, a seu juízo, praticada de meados do século XIX até os dias de hoje. O que o autor crê enxergar nesta tentativa de ordenar episódios e imperativos enfrentados por aquelas e aqueles que se dedicam a pensar 20 e produzir teoria política?

Vincent (2004, pp. 1-80) detecta cinco concepções ou elementos principais, embora não exclusivos, da teoria política que teriam demarcado o terreno da disciplina e ainda hoje penetrariam a percepção geral de sua natureza: as concepções normativa clássica, institucional, histórica, empírica e ideológica (como estudo das ideologias políticas) da teoria política. ${ }^{9}$ Esses vários modos de abordar e de se fazer teoria política, vale lembrar, também são tratados pelo autor (Vincent, 2004, p. 22) mais como tipos-ideais historicamente localizáveis - que podem sobrepor-se e/ou entrecruzar-se do que como modalidades de práticas acadêmicas que competiriam entre si.

\footnotetext{
9 Vincent (2004, pp. 10-12) lembra, em mais de uma passagem, que essas cinco concepções (ou modos de fazer teoria política) são as que, na sua visão, predominaram dos primórdios dessa prática disciplinar até nossos dias; apesar disso, insiste que não devem ser tomadas como modalidades exclusivas de "fazeres" da teoria política.
} 
A cada um dos diferentes modos de conceber e produzir teoria política elencados por Vincent corresponderia um "componente fundacional" - aqui, no sentido de um terreno definido sobre o qual a disciplina pode construir e encontrar sustentação. Assim, segundo ele, a teoria política normativa clássica - seja na versão da tradição da ordem e da natureza, da tradição empirista ou da tradição da razão histórica - tende $(\mathrm{u})$, tal como a filosofia política, a concentrar-se nos fins, na coerência e no significado ontológico, moral e prático da vida política e social. Se gregos e cristãos medievais dedicaram-se a refletir como deus ou a physis ordenariam o mundo e as coisas da política, os autores contratualistas criaram um repertório novo para um mundo novo, que agora pensa a vida política como artifício forjado pela vontade humana, guiada para alguns deles por paixões e interesses, para engendrar meios técnicos para a administração do mundo. Uma visão que seria desafiada no século XIX por pensadores comprometidos com alguma modalidade de razão histórica, segundo a qual vidas humanas são contingentes, frutos de seu tempo, mutáveis e, por isso, desprovidas de essências e/ou interesses universais. ${ }^{10}$

Entre os séculos XVIII e XIX, com a era das construções nacionais na América e em Europa, a teoria política ganharia contornos cada vez mais institucionais e tenderia a focar e articular o sentido e a prática estatais tanto como

\footnotetext{
10 Esta "tradição" adentraria, segundo Vincent (2004, p. 24), o século XX, chegando até, pelo menos, L. Strauss, e seria referência importante para pensadora(es) que proporiam refiná-la e aperfeiçoá-la - mas na chave de uma abordagem histórica da teoria política, como se discutirá a seguir -, entre os quais destacar-se-iam E. Voegelin, H. Arendt, H. Marcuse, T. Adorno e outra(os) - caracterizados por Vincent como autora(es) que teriam constituído a $1^{\underline{a}}$ onda do que ele denomina teoria política histórica, a ser tratada a seguir. Como se trata de uma construção típico-ideal, seu ponto aqui é mostrar que determinada(os) autora(es) podem ser vinculada(os) a mais de uma denominação. Esta 'tradição' normativa seria retomada no último quartel do século XX, sustenta Vincent (2004, p. 23), e constituiria, agora sob novas bases, importante referência para as teorias políticas contemporâneas, dos convencionalistas e comunitaristas até, em sua versão liberta da teleologia, Foucault e pós-modernos e pós-estruturalistas.
} 
ideia filosófica quanto como prática constitucional legal do Estado. Este tipo de abordagem marcaria o que Vincent denomina teoria política institucional. O grande modelo desta empreitada teria sido a tradição alemã da Staatslehre de matriz hegeliana, que aliava o estudo dos ideais normativos do Estado com suas formas constitucionais e empíricas, operando no entrecruzamento entre história, direito e teoria política. Este tipo de abordagem da teoria política se espraiaria por toda Europa, onde ganharia adeptos ilustres como M. Weber, É. Durkheim e F. Tönnies, e chegaria aos EUA por meio de acadêmicos como J. P. Burgess, W. A. Dunning ou C. Merriam, alocados nos recém fundados departamentos de ciência política.

O terceiro movimento teria tido lugar com as diferentes ondas impulsionadas pela teoria política de matriz histórica, que tende $(u)$ a compreender a disciplina primeiramente como uma sequência de contribuições teóricas inter-relacionadas que mantêm entre si um diálogo ou conversação acerca do que importa na política, razão pela qual o estudo da teoria política seria inescapavelmente histórico - um movimento que remontaria a Dilthey e Collingwood, passaria pelos grandes compêndios de história da teoria política, como aqueles organizados por Maitland ou Sabine, chegando até L. Strauss, E. Voegelin e H. Arendt, e que teria dado origem à "tradição" da teoria política como "história do pensamento político". ${ }^{11}$

A segunda onda deste movimento - que procuraria respostas para a contenda entre empiristas e normativistas, a ser aprofundada a seguir - teria sido propalada sobretudo pelas contribuições de intelectuais ligados ao "novo historicismo"

11 Em passagem célebre, que ilustra bem esta concepção de teoria política, Strauss (1957, pp. 344-345) explica que a 'teoria política' - à qual ele preferia referir-se como filosofía política - deve ser vista como a tentativa de "substituir a opinião sobre a natureza das coisas políticas pelo conhecimento das coisas políticas. [...] A filosofia política é a tentativa de conhecer verdadeiramente tanto a natureza das coisas políticas quanto a reta, ou a boa, ordem política". 
da Escola de Cambridge, entre as quais se destacam as de J. Pocock e Q. Skinner, que nos anos 1970 proporiam um método rigoroso, o contextualismo linguístico, ${ }^{12}$ capaz de superar o discurso inadequado de seus antecessores a respeito do passado e da "tradição", que havia preponderado na teoria política até então. Essa investida da chamada history in context seria, especialmente em razão da qualidade intelectual de suas(seus) formuladora(es), extremamente bem-sucedida e profissionalizaria o campo, assegurando, em meio à contenda teórica com o comportamentalismo cientificista, a autonomização da teoria política de matriz não empírica como área disciplinar.

Outra resposta aos desdobramentos experimentados na teoria política, sobretudo na primeira metade do século $\mathrm{XX}$, teria sido aquela desenvolvida pela teoria política empírica, que tende $(\mathrm{u})$ a concentrar-se na possibilidade de se estabelecer generalizações a respeito dos fenômenos políticos e de construir hipóteses testáveis e verificáveis, a partir das quais se pudesse fazer previsões, tal qual as ciências naturais. Para os fautores deste modo de operar com e a teoria política, entre os quais se destacam D. Easton, H. Lasswell, R. Dahl, K. Arrow e J. Buchanan, tal abordagem empírica da teoria política - seja a sua matriz o behaviorismo cientificista-positivista, que postulava uma separação categórica entre fatos e valores a ser apreendida pelo observador neutro, o pluralismo metodológico ou a teoria da escolha racional, também denominada teoria política positiva - seria superior a todos os outros modos de pensar e fazer teoria política, sendo capaz, inclusive, de falseá-las ou corroborá-las, além de poder

\footnotetext{
12 Esta seria, ao lado da teoria política normativa contemporânea, a concepção de teoria política que mais se desenvolveria no Brasil, institucionalmente abrigadas em grandes departamentos e programas de pós-graduação, com particular destaque para a USP e o atual IESP-UERJ (antigo IUPERJ), bem como na área temática (AT) da ABCP na última década. Para produções fortemente marcadas pela influência do contextualismo linguístico entre nós, cf. os seminais Jasmin e Feres Jr., 2006; Ostrensky, 2006; Feres Jr. e Jasmin, 2007; Silva, 2010.
} 
informar com evidências as políticas públicas e produzir designs institucionais e políticos.

Empiristas posicionados no campo a partir dessa concepção de produção teórica, inclusive, diagnosticariam, como fez D. Easton nos anos 1940-1950, o perecimento da [para eles, velha] teoria política. Seu obituário seria anunciado na célebre introdução de P. Laslett (1962[1956], p. vii), nos seguintes termos: "De todo modo, para o momento, a Filosofia Política está morta”. A declaração não tardaria, é claro, a ser contestada por pensadora(es) de matizes e inserções as mais distintas, de Strauss, Arendt ou Adorno a Pocock e Skinner, e alimentaria acalorados debates nos meios acadêmicos: ${ }^{13}$ estava aberta uma guerra que chegaria até nós de inúmeras maneiras. Talvez se possa afirmar com alguma propriedade que o apelo de S. Wolin em prol da busca de uma "vocação" da teoria política ${ }^{14}$ constitui um dos últimos ecos fortes desta disputa que distanciaria definitivamente a ciência política - que passava agora a ser monopolizada por

13 Contra a enunciação desse fim dramático e em defesa da filosofia política, John Plamenatz (1960, p. 37), p. ex. iria invocar o caráter "especulativo e empreendedor" do animal humano, enquanto I. Berlin chegaria a propor, em 1962, um modo específico de conduzir esta atividade - que estaria na origem do que comumente chamamos hoje de teoria política normativa -, descrevendo-a nos seguintes termos: "Quando perguntamos - o que é talvez a mais fundamental de todas as questões políticas - 'Por que uma pessoa obedece a outra pessoa?', não perguntamos 'Por que homens obedecem?' [...], nem ainda 'Quem obedece a quem, quando, onde e por quê?' [...] Quando perguntamos por que um homem deve obedecer, estamos pedindo a explicação do que é normativo em noções como autoridade, soberania, liberdade, e a justificação de sua validade em argumentos políticos" (Berlin, 2002, p. 105).

14 Nas primeiras páginas de Politics and Visions [1960], Wolin afirmava que esse modo de pensamento materializado na teoria política e na filosofia política não desfrutaria de uma essência conectada a uma natureza eterna ou a um princípio único. Para Wolin (1960, p. 3), nenhum corpus teórico, autor(a) ou momento histórico poderia oferecer uma definição fechada e conclusiva sobre esse modo de pensamento. Pois, como havia ensinado Nietzsche, só se define aquilo que não tem história. Se concluímos, sem dificuldade, que é absurda a afirmação de que um pintor ou escola representaria tudo aquilo que pode ser dito sobre arte e pintura, o mesmo poderia ser dito a respeito de quem pretende buscar uma única definição sobre a natureza da teoria/filosofia política. 
teórica(os) que abraçavam uma concepção empirista-cientificista da produção de conhecimento, num movimento que expulsaria do campo seus antigos teóricos - da teoria política que professava outros cânones. ${ }^{15}$

Por fim, Vincent aponta ainda para os desenvolvimentos da teoria política na direção das ideologias políticas, para ele, um caso que se relaciona de maneira mais especial e contestada com a teoria política e que poderia ser encontrado - dado que sua tipologia pretende ser típico-ideal em autores localizáveis também em alguma das quatro concepções anteriores. Para as(os) autoras(es) que privilegiam essa abordagem, a teorização é e sempre foi um modo de

15 J. Gunnell (2011, pp. 22-28) oferece, a partir do caso norte-americano, uma interpretação distinta dos acontecimentos aqui brevemente enunciados: segundo ele, a ciência política comportamentalista que se consolidava nos EUA após 1920 abraçaria a democracia e se empenharia na construção de uma teoria pluralista da democracia baseada em métodos científicos testáveis e verificáveis, em um movimento que tornava a história do pensamento político como fora praticada até então 'obsoleta', peça de 'antiquário'. Entretanto, esse também foi o momento em que a academia norte-americana experimentou o encontro com os [sic] "pensadores judeus-alemães emigrados" aos EUA, aos quais forneceriam referências novas à teoria política e à ciência política no país. Embora conservassem o núcleo normativo forte de seus antecessores, agora, entretanto, na forma de filosofia transcendental e fundacional, essa geração de emigrados, que desconfiava do pluralismo liberal e do pragmatismo americanos e desdenhava a pesquisa empírica e a política, continua Gunnell (2011, pp. 23-24), conseguiria firmar-se como teóricas(os) políticas(os), despertando a ira de cientistas políticos comprometidos com o cientificismo empirista, como D. Easton, que encamparia nos anos 1950-1960 um movimento que culminaria na separação e "alienação" da teoria política do campo da ciência política, da qual a decretação da 'morte' da teoria política por Lasllett em 1956 foi apenas uma entre tantas manifestações. Neste contexto, a "vocação" da teoria política para o estudo da "tradição", no dizer de S. Wolin (1969), apenas sacramentava a realidade desse apartamento e decretava a autonomia da teoria política norte-americana em relação à ciência política, sua casa institucional. Este percurso na direção da autonomização da área seria consolidado logo depois, ao longo dos anos 1970, por meio do trabalho de intelectuais ligados ao "novo historicismo" da Escola de Cambridge. Ao mesmo tempo, o distanciamento gerado por tal processo teria criado uma divisão intelectual do trabalho entre a ciência política e a teoria política norte-americanas, primeiro entre uma teoria histórica e outra empírica da política que, depois da virada normativa introduzida por J. Rawls nos anos 1970 e encampada nos anos 1980 pelos pensadores (neo)republicanos e pelos teóricos críticos, gestaria também a teoria normativa da política. Cf. Gunnell, 1987 e 1993; Ball, 1995 e 2004; Feres Jr., 2000. 
pensar profundamente prático e diretamente conectado à esfera da ação política. Oitocentista, nascido como "ciência empírica das ideias" (cf. Vincent, 2004, p. 65), o conceito de ideologia esteve sempre associado, de algum modo, à reflexão teórica e se relacionaria com a produção de conhecimento em teoria política de duas maneiras básicas: da perspectiva de uma integração ou de uma segregação entre teoria política e ideologia política, podendo cada uma dessas modalidades ser compreendida de maneira positiva ou negativa.

A visão mais conhecida - mas não a única - de integração negativa é talvez a de Marx, para quem o liberalismo, por exemplo, era a ideologia - sustentada pela "falsa consciência" - produzida por filósofos ou teóricos políticos burgueses ocupados com as aparências, que encobrem as relações reais de produção (Vincent, 2004, p. 66). Já a integração positiva será a tônica daquelas(es) pensadoras(es), como R. Ashcraft, que acreditam ser impossível separar produção de conhecimento de nossas ações e concepções políticas, ou certos teóricos discursivos, para os quais ideologias políticas e teorias políticas não representam o mundo nem refletem com neutralidade sobre ele, mas muito mais o constituem, estando enredadas em relações complexas e disputas de poder (Vincent, 2004, pp. 67-69). Segregação negativa, por sua vez, a visão mais comum ao longo do século XX, é aquela que distingue o empreendimento nobre, reflexivo e/ou superior levado a cabo pela filosofia ou teoria política do partidarismo vulgar, reducionista e/ou manipulador da ideologia e dos ideólogos (Vincent, 2004, p. 70). Por fim, segregação positiva é a denominação usada por Vincent para nomear abordagens como as de M. Freeden, para quem tanto a teoria política como as ideologias políticas - que entende como sistemas de pensamento-ação incorporados na linguagem escrita e falada - fornecem insights igualmente válidos e tanto refletem quanto produzem realidades políticas e sociais: ideologias devem ser vistas como "mapas 
para navegação no domínio político" e constituiriam, ao lado da filosofia política, subcategorias de um campo maior, o da teoria política (Vincent, 2004, pp. 71-72).

$\mathrm{O}$ instigante panorama oferecido por Vincent neste primeiro capítulo, embora menor e secundário no conjunto da obra, parece-nos digno de uma reflexão mais aprofundada e esteve por trás das preocupações que nortearam as iniciativas antes mencionadas, que ora se materializam neste dossiê. Aquele diagnóstico inicial a respeito da multiplicidade vocabular e da polifonia que acompanham a diversidade de abordagens, concepções e fundações da teoria política conduziu-nos a uma reflexão sobre por que e como enfatizar a distinção entre pluralismo e pluralidade poderia ajudar-nos a pensar a autonomia do campo.

Contra a valorização deste entendimento, poder-se-ia objetar que a reconstrução proposta por Vincent diria respeito a uma narrativa centrada nos desenvolvimentos europeu e anglo-americanos da teoria política e ocuparia, portanto, um lugar de enunciação que não nos diz respeito e/ou que não compartilhamos. Ainda assim, não seria difícil demonstrar que a teoria política produzida entre nós mantém, em um mundo que é cada vez mais interconectado e global, intenso e frutífero intercâmbio com as "tradições" engendradas alhures, nelas bebendo, deixando-se inspirar e com elas mantendo trocas nada desprezíveis. Além disso, podemos detectar na produção brasileira ${ }^{16}$ inserções

\footnotetext{
16 Apenas para exemplificar, mencionamos alguns trabalhos de acadêmicas(os) brasileiras (os) que têm ou tiveram entradas significativas em alguma - e, por vezes, em mais de uma - das concepções de teoria política tipificadas por Vincent e/ou que dialogam intensamente com o campo, permitindo que se verifique, também entre nós, a presença destas distintas visões do fazer teórico. Cf, p. ex., entre muitas(os) outras(os), Araújo, 2013; Avritzer, 1994; Bianchi, 2008; Biroli e Miguel, 2012, 2013; Branco, 2011; Codato e Perissinotto, 2011; Cohn, 2003; Eisenberg e Pogrebinschi, 2002; Mendonça, 2013; Feres Jr., 2005; Ferreira, 2004; Jasmin, 1997; Kerstenetzky, 2012; Koerner, 2015; Lacerda, Perissinotto e Szwako, 2016; Lavalle, 2004; Rego e Pinzani, 2013; Lessa, 1998; Lynch, 2014; Matos, 2013; Melo, 2011; Mendes, 2013; Mendonça, 2003; Miguel, 2005; Pinto, 2017; Quirino, Brandão e Vouga, 1998; Reis, 1990; Silva, 2008b; Vita, 2007. Os trabalhos aqui elencados
} 
e concepções muito similares àquelas "tipificadas" por Vincent, as quais não raro ajudam a explicar os dissensos entre as(os) que operam o e no campo.

Por tudo isto, parece-nos possível concordar com a conclusão de Vincent a respeito das concepções ou elementos do campo da teoria política por ele identificados, qual seja, a de que "não há uma essência imaculada [pristine essence] da teoria política. A teoria política é e sempre foi uma desconfortável combinação de diferentes modos de pensamento." (Vincent, 2004, p. 74). Neste sentido, a definição do que seria teoria política tem sido incansavelmente disputada ao longo dos séculos - e tudo indica que continuará a sê-lo, dado que as contendas, aqui como alhures, parecem - ainda bem! - longe de um fim. Ao invés de mirar esses diferentes modos de operar com e de fazer teoria política como concorrentes entre si, talvez ganhássemos mais e, principalmente, avançássemos mais se nos dispuséssemos a mirar o campo de maneira mais plural e multifacetada - "ecumênica", para tomar de empréstimo uma metáfora de Vincent -, enxergando nestas "concepções" mais subcampos ou subáreas da teoria política - que exigem das partes o respeito à multiplicidade de vocabulários existentes bem como a disposição para a "tradução" -, e menos modos excludentes de operá-la. Como se pode justificar - teoricamente - essa posição, é o que discutiremos a seguir.

\section{Pluralidade, pluralismo e autonomia}

Este dossiê pode ser lido como uma tentativa de mostrar como a teoria política contemporânea é feita no plural tanto porque o campo é plural quanto porque o pluralismo epistêmico é um valor definidor de suas práticas. O objetivo

foram selecionados com o intuito de fornecer uma pequena mostra da diversidade do campo. Nossa escolha carrega, é claro, certa dose de arbitrariedade: haveria, por certo, inúmeros outros nomes de autoras(es) com inserções fortes na teoria política que poderiam ter sido aqui nomeadas(os). 
desta seção é justificar de que modo o pluralismo e a pluralidade são partes da produção de conhecimento levada a cabo no campo da teoria política. De modo um pouco mais arriscado, pretendemos também sugerir que, talvez por meio do reconhecimento do pluralismo e da pluralidade como características da teoria política, poder-se-ia encontrar os traços definidores de sua autonomia diante de outros modos de produzir conhecimento.

Sustentar, lado a lado, que a teoria política contemporânea é pluralista, plural e autônoma exige enfrentar - ou expor - uma tensão entre, de um lado, traços que indicam o plural e a diferença e, de outro, características que nos fazem aceitar que existe algum tipo de unidade. Para dar conta dessa característica, propomos recolocar o diagnóstico da multiplicidade, para continuarmos com os termos da seção anterior, com base em uma distinção entre (i) a constatação da pluralidade de teorias e (ii) o reconhecimento do pluralismo epistemológico. ${ }^{17}$

Comecemos pelo último. A publicação de Uma teoria da justiça [TJ - 1971] não foi responsável apenas por conferir novo sopro de vida à teoria política em geral. Como observou Álvaro de Vita, o trabalho de J. Rawls restaurou “a teoria política normativa, enquanto tal, como uma área do conhecimento" (Vita, 2008, p. XI), recolocando no centro do debate das teorias políticas contemporâneas questões sobre justiça social, igualdade, tolerância e outros temas candentes. ${ }^{18}$ Para além de exegeses ou de algum tipo de leitura estrutural, aceitamos aqui que estar de acordo com o

\footnotetext{
17 Agradecemos à Lucas Petroni a disposição de debater e colaborar com a elaboração dos termos do argumento que se segue.

18 Para uma visão alternativa sobre o papel de Uma teoria da justiça nesse contexto de "revitalização da teoria política", cf. Parekh, 1998, que recusa a ideia de que os anos 1950 e 1960 teriam representado o declínio ou a "morte" da teoria política, o que, consequentemente o leva a recusar que a publicação de Uma teoria da justiça poderia representar seu renascimento. Para outras posições no debate em torno do papel de Teoria de Justiça, cf. Young, 1998; Barry, 1998.
} 
espírito da teoria rawlsiana nos leva a pensar com Rawls, e não apenas sobre Rawls. Esta é justamente a nossa pretensão quando nos voltamos para um aspecto específico da sua teorização, o pluralismo. ${ }^{19}$

Há ao menos dois sentidos em que a ideia de pluralismo é empregada nos escritos rawlsianos. O primeiro é enfatizado na famosa tese do pluralismo, de acordo com a qual valores morais podem entrar em conflito, o que nos impede de encontrar uma configuração institucional "perfeita" capaz de harmonizar todos os valores que são desejados por cada um ao mesmo tempo. A dupla herança aqui é óbvia: o conflito de valores, tal como formulado por Berlin (2002); e o politeísmo de valores, como expresso por Weber (1972). ${ }^{20}$

No entanto, Rawls emprega a ideia de pluralismo também em outro sentido, o do pluralismo razoável. Em O liberalismo político [LP - 1993], podemos encontrar a tese de que

19 Não parece controverso afirmar que essa é umas das características marcantes do modo como Vita pensou a teoria política normativa que designou, de modo mais ou menos intercambiável, liberalismo igualitário ou justiça rawlsiana (cf. Vita, 2008): não é seguindo ao pé da letra excertos da Teoria da justiça ou de O liberalismo político que o teórico político pensa sobre conflitos e problemas normativos controversos, e sim construindo uma teoria política orientada a problemas, para ficamos com os termos propostos por Ian Shapiro (2002), que nos permita pensar a respeito dos desacordos morais relevantes que marcam as nossas sociedades democráticas. 20 É importante lembrar que Rawls faz distinção entre a formulação do conflito pluralista em Berlin e Weber. Em Berlin - posição ratificada por Rawls -, o reino dos valores é objetivo; no entanto, esses valores chocam-se uns com os outros, impondo às instituições - marcadas pela incapacidade de abarcar todos esses valores - demandas que entram necessariamente em conflito. "Que não exista mundo social sem perdas", assume Rawls (2011, p. 233), "está é uma contingência que está arraigada na natureza dos valores e do mundo, e grande parte da tragédia humana é reflexo disso". Já a posição de Weber constitui, segundo Rawls (2003, pp. 154-155), uma forma de ceticismo de valores nascida do conflito entre vontades resolutas. O problema, segundo ele, que, de acordo com essa formulação subjetivista do pluralismo de valores, esses seriam contingentes ou nunca poderiam ser razoáveis segundo uma métrica externa. Há, no entanto, outra interpretação da tese weberiana, que incorpora o traço da diferenciação das esferas de valores como traço da modernidade (cf. Habermas, 2000, pp. 4-5). Nesse sentido, valores não são interpretados apenas como resultado do voluntarismo de cada um, e sim vividos em cada esfera - ou sistema, para permanecermos nos termos de Habermas -, as quais desfrutam de lógicas e critérios de validação autônomos. 
existem conflitos irreconciliáveis de valores, mesmo entre pessoas perfeitamente razoáveis - o plano aqui é o da teoria ideal. ${ }^{21}$ Isto porque, para o filósofo norte-americano, as pessoas gozam de duas capacidades morais fundamentais em grau suficiente para serem cidadãos e cidadãs livres e iguais: a capacidade de ter um senso de justiça - entender, aplicar e agir de acordo com princípios de justiça; e a capacidade de ter uma concepção de bem - dos fins objetivos que são merecedores do empenho de cada um (cf. Rawls, 2011, p. 123). Essas, no entanto, não são as características da comunidade epistêmica que dão forma ao campo da teoria política contemporânea.

Vale a pena arriscar, parece-nos, imaginar uma analogia entre a comunidade democrática pluralista rawlsiana, de um lado, e a comunidade epistêmica de teóricas(os) políticas(os), de outro. Se os diagnósticos feitos até aqui estiverem corretos, parece ser possível sustentar que as teorias políticas contemporâneas - das mais diferentes tradições e matizes - não apenas convivem, e podem conviver, em um espaço de diversidade - o que caracterizamos como pluralidade-, como também parecem incorporar essa pluralidade à sua autocompreensão, o que podemos caracterizar como pluralismo. Vejamos.

A possibilidade de um consenso racional acerca dos múltiplos valores - muitos deles, irredutíveis - formulados por republicanos, comunitaristas, liberais, feministas, pós-estruturalistas, teóricas e teóricos críticos etc., é, como sabemos, impossível. Sendo assim, parece factível sustentar que teorias perfeitamente coerentes, empiricamente embasadas e razoáveis em suas demandas e consequências podem conviver em um espaço de razões, o que só é possível

${ }^{21}$ Isto é, o conflito de valores não é apenas fruto de limitações contingentes entre as(os) agentes envolvidas(os) numa relação, mas algo a ser esperado mesmo entre pessoas idealmente razoáveis. Para uma discussão sobre teoria ideal e teoria não-ideal, cf. Simmons, 2010; Valentini, 2012; Stemplowska e Swift, 2012. 
por reconhecerem - explícita ou implicitamente - os limites do alcance de teorizações formuladas em um contexto que necessariamente admite a possibilidade de desacordos razoáveis. Reconhecer os limites da nossa capacidade de teorização, levar isso a sério e operar de maneira consequente a partir desta base - o que não equivale de modo algum a subscrever o fracasso da teorização -, pode ter papel similar àquele das condições de possibilidade de um pluralismo razoável em uma comunidade democrática.

Em um exercício imaginativo que procura avançar na direção de construir uma fundamentação adequada para a defesa da ideia de que a teoria política é, e deve continuar sendo, uma empresa pluralista, os "limites da capacidade do juízo" serão interpretados e, em alguma medida, reformulados como teses epistemológicas. ${ }^{22}$ Tal exercício pode ser entendido como resultado de uma reflexão sobre as consequências da adoção do pressuposto de que as teorias políticas se autocompreendem como falíveis - o que poderia ser explicado por meio de teses sobre a modernidade, da crítica à Razão (maiúscula), da impossibilidade de se falar em totalidade etc. - e se colocam em um espaço de disputa no qual pluralismo é um fato e um valor. Parece-nos factível sustentar que podemos pensar os limites do julgamento teórico a partir de quatro aspectos:

(a) Impregnação teórica. As observações são impregnadas teoricamente. Não existe evidência autoexplicativa ou autoexplicável: precisamos de teorias para definir nossos objetos, mas também precisamos - como podemos aprender com a antropologia - de teorias para apreendê-los; e, se são objetos que envolvem a política, então precisamos de teorias

${ }^{22}$ É verdade que, em sua formulação original, o argumento do limite das capacidades do juízo também possui um núcleo epistemológico (cf. Rawls, 2011, pp. 67-68). Para Rawls, no entanto, os limites da capacidade do juízo possuem ao menos duas dimensões distintivamente práticas (as características denominadas "e." e "f.") que, dada a natureza da nossa discussão, não iremos tratar. 
políticas. É o que nos ensina, por exemplo, N. R. Hanson (1958, p. 19), quando afirma que ver é uma atividade essencialmente teórica, ou ainda R. Lessa (1998, s/p): "Nenhum dado fala. Os dados são portadores incuráveis de afasia. Eles não têm o dom da palavra. Nós é que temos. Nós é que sabemos perguntar.";23

(b) Subdeterminação empírica das teorias. Mesmo que se concorde com diferentes considerações relevantes, ainda assim podemos discordar quanto à sua importância relativa. Ou seja, mesmo que os dados estejam estabilizados, ainda há espaço para a indeterminação. Um exemplo pode nos ajudar a ilustrar esse ponto: o muro que representava a bipolarização do mundo foi derrubado em 1989. Poucas(os) questionariam o evento em si - a queda do muro; o que se disputa é, por exemplo, se o evento (a queda) representaria o fim das possibilidades do socialismo real, ou o triunfo do capitalismo, ou ainda o início da verdadeira realização do socialismo, e assim por diante, ${ }^{24}$

(c) Indeterminação conceitual. Conceitos, inclusive, os morais e políticos, são, em alguma medida, vagos e sujeitos a casos difíceis de aplicação. Recorrer ao texto de Rawls (2011, p. 67) pode ajudar a esclarecer tal ponto: "Esta indeterminação significa que devemos nos ater a juízos e interpretações (e a juízos sobre interpretações) que se encontrem em um leque de variações (que não é possível especificar de forma precisa) dentro do qual pessoas razoáveis podem divergir". A indeterminação, que não se traduz na paranoia da vagueza - isto é, a tese metafísica segundo a qual nenhum conceito pode ser linguisticamente determinado - é condição para que desacordos conceituais possam ocorrer. O espaço para disputas e para dissenso é, nesse sentido,

23 Para uma discussão mais aprofundada sobre o conceito de impregnação teórica na ciência, cf. Bogen, 2017.

${ }^{24}$ Para uma discussão mais aprofundada sobre o conceito de subdeterminação empírica, cf. Quine, 2011. 
consequência da adoção de uma formulação sobre os limites da capacidade do juízo.

Do mesmo modo que fatos não são autoexplicáveis, conceitos não são autointerpretáveis. Uma forma possível de lidar com a indeterminação conceitual é reconhecer a distinção entre conceitos e concepções: um mesmo conceito, como, por exemplo, o de liberdade, república ou justiça, pode admitir diferentes concepções que, por sua vez, admitem interpretações antagônicas entre si (cf. Hart, 1961; Rawls, 2008; List e Valentini, 2016). Ou seja, ainda que o núcleo semântico do valor de liberdade, por exemplo, possa ser estável entre diferentes teorias políticas, o conceito de liberdade permanece indeterminado caso não seja formulado por meio de concepções particulares, como a republicana, a libertariana, a socialista etc. Isso explica, inclusive, porque os conceitos fundamentais da teoria política são permanentemente contestados (faz parte do jogo teórico esse tipo de contestação) - o que não equivale necessariamente a afirmar que conceitos sejam essencialmente contestáveis (cf. Gray, 1977; Clark, 1979) $;^{25}$

(d) Dependência do contexto. Juízos teóricos podem divergir também porque "a maneira como avaliamos as evidências e como pesamos valores morais e políticos está condicionada pela totalidade de nossa experiência, por toda a vida que levamos até o momento, e a totalidade de nossas experiências sempre difere" (Rawls, 2011, p. 67). Rawls está chamando atenção para a dependência dos juízos teóricos em relação a um horizonte histórico, contextual e temporal, o qual podemos avaliar de modo crítico, mas do qual nunca podemos escapar completamente - décadas depois, nas

25 Para visão alternativa segundo a qual os conceitos são, necessariamente, essencialmente contestáveis, confere Ricardo Silva, que dedicou grande parte dos seus escritos a expor e discutir as teses de W. Gallie e a relevância de sua adoção pelas ciências humanas e para o debate em torno do republicanismo em particular. Cf. Gallie, 1955; Silva, 2011 e 2015. 
quais noções como essa foram intensamente debatidas e disputadas, pensadoras(es) autointituladas(os) radicais formulariam teorias interessantes e críticas, mas assumidamente parciais, a partir da ideia que se convencionou chamar de lugar de enunciação. ${ }^{26}$

Negar uma dessas quatro características não é uma impossibilidade racional, sabemos: é perfeitamente possível teorizar - e foi essa a regra até pouco tempo - sem aceitar o valor de um pluralismo epistemológico razoável. Mas acreditamos que merece menção a esta altura da discussão uma constatação importante: negar uma dessas quatro teses implica comprometer-se com uma atividade de teorização que nenhuma teórica ou teórico poderia razoavelmente isto é, por meio de razões boas e suficientes - rejeitar, dadas as condições de produção de conhecimento que conformam nossa comunidade epistêmica hoje. Do mesmo modo, recusar o valor epistêmico do pluralismo e, consequentemente, o limite da capacidade do juízo teórico, significa recusar também que o conflito e a possibilidade do entendimento ${ }^{27}$ [Verständnis] - e não a harmonia e o consenso - são as marcas da produção de conhecimento do que comumente cha-

${ }^{26}$ A afirmação de que juízos teóricos dependem, em alguma medida, do lugar de enunciação de quem o produz, pode parecer surpreendente para alguma(ns) leitoras(es) de Rawls; obviamente, não pretendemos sustentar aqui que Rawls teria traduzido e levado esse argumento às últimas consequências para a produção de conhecimento teórico-político: como se sabe, tal inflexão viria das feministas e das teóricas e teóricos pós-coloniais e de-coloniais. A importância de olharmos, enquanto produtoras e produtores de conhecimento, para quem está produzindo teoria, qual o lugar de fala e para quem se está falando/comunicando é justificada nos trabalhos de importantes teóricas(os), aqui e noutras partes. Cf. Bhabha, 2002; Hall, 1992; Haraway, 1988; Latour, 2005; Mouffe, 1995; Butler; Laclau; Žižek, 2000; Collins, 1986; Mignolo, 2008; Costa, 2006; Mendonça; Rodrigues, 2008; Ballestrin, 2017.

27 Optamos pelo termo "entendimento" por compreendermos que a palavra preserva o sentido conflituoso das trocas humanas: podemos entender e, ainda assim, não concordar. Na língua alemã, essas ideias estão são expressas por meio do vocábulo Verständnis, aqui mobilizado para indicar o sentido de nossa afirmação: é para a dimensão racional do termo entendimento que queremos atentar quando o invocamos neste contexto. 
mamos de modernidade- ou contemporaneidade, como preferem outras(os).

Aceitar tais condições, por outro lado, permite, entre outras coisas, falar de pluralismo sem recair necessariamente em um relativismo teórico: reconhecer os limites das capacidades teóricas - de conceitos, juízos, concepções, avaliações de evidências e de nossos "lugares" de produtoras(es) de um tipo específico do conhecimento - significa admitir não o fracasso do empreendimento teórico, e sim que o "fazer" teórico tem tanto aspectos contingentes quanto conflituosos e, dada sua condição de parcialidade, poderia ser mais bem exercido se fosse compreendido e tomado como um empreendimento coletivo - como projeto interminavelmente inacabado, para remeter a leitora ou o leitor a uma famosa imagem da modernidade.

Expostos os argumentos em defesa de um pluralismo epistemológico, resta-nos discutir nossa primeira assunção: a pluralidade de teorias. Com esse debate não pretendemos recolocar as questões já tratadas por D. Leopold e M. Stears (2008); mas julgamos que, para além dos métodos e metodologias das ciências humanas ${ }^{28}$ (muitos deles inspirados nas ditas ciências duras, como é o caso de boa parte das teorias políticas empíricas), ${ }^{29}$ haveria ainda algo mais a ser dito sobre a pluralidade e que poderia integrar as mais variadas perspectivas teóricas: o seu objeto.

Stephen White e Donald Moon (2004) apontam para um traço que nós, pesquisadoras e pesquisadores dedicadas(os) à teoria política, não mais podemos ignorar: depois da definição oferecida por Foucault (2005) à noção

\footnotetext{
${ }^{28}$ Para formulação sobre como a teoria política emprega métodos e metodologias das ciências humanas, cf. Grant, 2002.

29 Para discussão mais aprofundada sobre teoria política empírica, cf. Beyme,1998. Para discussão sobre teoria da escolha racional e sua relação com a teoria política, cf. Barry, 1998 (em especial a primeira seção); Shapiro e Green, 1994. Entre nós, uma interessante reflexão sobre o tema foi produzida por Reis, 1990; Carvalho, 2008.
} 
de poder e, principalmente, depois da crítica feminista radical de que o pessoal é político, ${ }^{30}$ ainda seria possível definirmos um único objeto ao qual a teoria política devesse se dedicar? Poderíamos ir além, talvez, refletindo sobre o problema da definição do objeto classicamente pensado como próprio da teoria política, seu tema por excelência, segundo muitas(os), ao menos até meados do século XX, qual seja, o Estado e seus termos correlatos - soberania, cidadania, autoridade política, legitimidade, coerção, fronteira, território, nação, povo e assim por diante -, em um cenário no qual novas(os) atrizes e atores e, com elas(es), novos problemas, teóricos e práticos, emergem.

Não é preciso aceitar os diagnósticos cosmopolitas mais controversos para reconhecer um movimento que já ocorre no globo há algum tempo e que indica a necessidade de se pensar sobre temas que antes foram definidos dentro das fronteiras e do arcabouço teórico do Estado nacional, soberano e territorialmente delimitado. Cada vez mais temos deparado com pesquisas sobre justiça global, cidadania cosmopolita, espaço público global/transnacional, movimentos sociais transnacionais, patriotismo constitucional, responsabilidade internacional, constitucionalismo transnacional etc., para ficarmos apenas com alguns termos do debate de uma teoria política internacional. ${ }^{31}$

Se os objetos e preocupações teóricos ampliaram-se consideravelmente quando estudiosas e estudiosos precisaram lidar com a descentralização - e não o fim, note-se bem! - dos Estados como fonte de preocupação analítica e normativa, o mesmo ocorreu quando tiveram de enfrentar-se

\footnotetext{
${ }^{30}$ Para discussão mais pormenorizada da crítica feminista que ficou conhecida por meio do slogan "o pessoal é político", cf. o artigo deste dossiê escrito por Flávia Biroli. Para um aprofundamento do tema do poder pós-Foucault, cf. Brown, 2006. 31 Para alguns dos vários temas elencados aqui, cf. Beitz, 1983; Pogge, 2001; Benhabib, 2006; Brock, 2009; Brown, 2000; Fraser, 2014; Habermas, 2001; Neves, 2012; Young, 2011; Keck e Sikkink, 1998; Kaldor, 2003, etc.
} 
com a ideia de que o poder é exercido em rede ${ }^{32}$ ou de que o "pessoal é político". A família e o privado passaram a constituir temas incontornáveis de quem debate justiça ou direito, por exemplo. O corpo e o modo como normas jurídicas, políticas sociais e culturais criam sujeitos que aparecem na esfera pública tornam-se fonte de preocupação. O problema da representação, ou de sua falta, seus múltiplos lugares, adentra os debates sobre o modo como ideias e pessoas podem ou não ser representadas. ${ }^{33}$ Também o direito e suas práticas, em conexão com o poder e o saber, passam a ser tratados a partir de uma análise tanto de suas configurações concretas quanto de suas continuidades e mudanças históricas, num movimento que abriria espaço para pesquisas sobre a racionalidade jurídica de experiências sociais que se refletem na arte de julgar. ${ }^{34}$ Todos esses movimentos, somados a outros tantos que não caberiam no espaço desta apresentação, imporiam refletir sobre a(s) origem(ns) de nossos arcabouços teóricos, questionar a validade das definições acerca de quem é o centro ou a periferia, ${ }^{35}$ produzir teorias de-coloniais etc., exigindo de nós o esforço de formular tra-

32 Foucault afirma, em Em defesa da sociedade [1997], que "O poder se exerce em rede, e nessa rede, não só os indivíduos circulam, mas estão sempre em posição de serem submetidos a esse poder e também de exercê-lo. Jamais eles são o alvo inerte ou consentidor do poder, são sempre seus intermediários. Em outras palavras, o poder transita pelos indivíduos, não se aplica a eles [...] O indivíduo é um efeito do poder e é, ao mesmo tempo, na mesma medida em que é um efeito seu, seu intermediário: o poder transita pelo indivíduo que ele constitui." (Foucault, 2005, p. 35).

33 Cf. Pinto, 1994; Cyfer, 2015; Young, 2011; Phillips, 1997; Lüchmann, 2007; Lavalle e Vera, 2011; Miguel, 2003; 2011; Almeida, 2014.

34 Em alguns de seus trabalhos, Andrei Koerner reflete sobre a relação entre direito, poder e saber, oferecendo, para além de uma interpretação dos textos de Foucault, trabalhos empíricos orientados por um quadro analítico em que a arte de julgar é interpretada como locus privilegiado para que racionalidades governamentais expressas em racionalidades jurídicas possam ser desveladas. Cf. Koerner, 2012 e 2015.

35 Para um trabalho instigante que lança mão dessa distinção em uma chave analítica original, qual seja, a partir do modo como os agentes - nesse caso, pensadora(es) e teórica(os) da política - se reconhecem, cf. Lynch, 2016. 
duções e de responder, de diferentes modos, à pergunta: $O$ subalterno pode falar? ${ }^{36}$

Caberia ainda uma nota final - exploratória - a respeito da autonomia da teoria política. ${ }^{37}$ Tendo em vista que todo esforço aqui mobilizado procurou responder à pergunta inicial sobre a relação entre o diagnóstico da multiplicidade e da polifonia, de um lado, e a unidade de um saber que poderia ser chamado de teoria política, de outro, argumentamos que a disposição de levar a sério a pluralidade e o caráter eminentemente coletivo da produção de conhecimento podem não ser traços exclusivos da teoria política; mas parece ser factível afirmar que o cultivo desse ethos em nossa prática constitua traço definidor da autonomia do campo. ${ }^{38}$ Quando se assume que o pluralismo é também epistemológico e o campo da teoria política, necessariamente plural, a afirmação sobre a cooperação como parte incontornável da produção de teoria política contemporânea ganha sentido

${ }^{36}$ Para trabalhos seminais de autoras feministas que deram origem a esta literatura, cf. Mohanty, 1988; Spivak, 2010; cf. tb. Ballestrin, 2017, entre outros.

37 Não poderemos nos limites desta introdução explorar porque a autonomia é parte do diagnóstico que estamos propondo. No entanto, a afirmação dessa característica pode ser lida como parte dos argumentos que devem ser explorados em texto posterior.

38 Reconhecemos que o argumento em favor de nossa posição não foi ainda devidamente fundamentado. Esse é um passo necessário para podermos afirmar a autonomia do campo e sua ausência pode, inclusive, abrir espaço à interpretação de que a defesa do pluralismo e da pluralidade impediriam a afirmação da unidade da teoria política. Como não há espaço para tanto neste momento, optamos por propor apenas uma direção de resposta à possível conclusão a respeito da impossibilidade de unidade. Poderíamos indicar a existência de um fio condutor que alinhava a multiplicidade de modos por meio dos quais a teoria política foi - e continua a ser - pensada e feita, qual seja, o sentido da orientação da atividade teórica para a(o) política(o). Argumentamos ao longo do texto que tal orientação gera uma multiplicidade de modos de pensar o "fazer" da teoria política; e, mais, que seu objeto não mais se limita ao Estado e seus termos correlatos, ao público e aos vários modos por meio dos quais essa categoria foi apreendida ou ao poder identificado com um único agente e/ou estrutura. Mas, ainda sim, parece possível concluir, agora com E. Frazer, que a teoria política é orientada a um sujeito - que é a (o) política(o). Daí, inclusive, o sentido da pergunta: "qual é a 'política' sobre a qual devemos produzir teoria?" (Frazer, 2008, p. 172). Os argumentos em favor desta posição, no entanto, precisam ser ainda melhor demonstrados. 
eminentemente epistemológico, que esteve desde o início, embora talvez não tão claramente, no coração das intenções que nortearam este dossiê.

\section{Breve apresentação}

Os textos oferecidos a seguir neste dossiê cumprem, a nosso ver, o papel de dar início ao debate - que, pretendemos, seja plural e epistemologicamente pluralista - a respeito dos modos e "fazeres" da teoria política. Espera-se que, com isso, novas discussões e problemas se imponham, permitindo-nos avançar e sofisticar a qualidade das disputas hoje presentes no campo. Há, ainda, muito sobre o que dialogar, e a teoria política produzida no Brasil pode, sem dúvida, contribuir para esta empreitada, como acreditamos ficará evidente por meio das contribuições reunidas para este dossiê.

O primeiro artigo, de Alessando Pinzani, aborda a 40 famosa contenda histórica entre teóricos positivistas e teóricos críticos, por meio da qual explora o argumento de que todas as teorias políticas, mesmo as mais supostamente científicas, recorrem a critérios axiológicos - seja na escolha de seus temas, seja na definição dos conceitos - e partem, portanto, de alguma base normativa - o que não equivale necessariamente a afirmar que sejam prescritivas. Segundo Pinzani (p. 76), as teorias prescritivas tendem a tratar a atividade política como simples aplicação de princípios normativos predefinidos, enquanto teorias não prescritivas defenderiam que "a política consiste justamente na busca pública de soluções a problemas concretos” (p. 76).

Na segunda parte do artigo, o autor retoma a teoria crítica imanente de M. Horkheimer e T. Adorno, em diálogo com Honneth, para sustentar que "as causas das patologias sociais objetos da crítica social são intrinsecamente ligadas às instituições e às práticas sociais que caracterizam a sociedade moderna e contemporânea", concluindo que os 
déficits diagnosticados por Honneth constituem muito mais o "resultado lógico do desenvolvimento do potencial opressor intrínseco do Estado, da economia capitalista e da família burguesa” (p. 86), razão pela qual seria mister resgatar a - necessária e inevitável - dimensão econômico-material, sem a qual não se realiza, para ele, a vida humana.

No artigo seguinte, escrito por Álvaro de Vita a partir de uma perspectiva frontalmente oposta à anterior, o autor procura argumentar, em consonância com I. Shapiro (2002) e a partir da teoria política normativa de matriz rawlsiana, que teorias políticas deveriam orientar-se não pelo método, por técnicas ou pela própria teoria, e sim pelos problemas de seu tempo, procurando explicitar e justificar de maneira racional os princípios que assume, confrontando-os com outros princípios que se lhe opõem e com suas possíveis implicações institucionais. Para mostrar como pode-se levar a cabo tal intento, recorre a dois exemplos de questões controversas na teoria política que julga permitir revelar as características centrais - que envolvem tanto posturas metodológicas quanto substantivas - do modo de praticar a reflexão política normativa por ele defendida.

O primeiro exemplo - que é quase um dilema - mobilizado por Vita é o de saber se uma concepção de justiça "deve ter por objeto instituições e políticas públicas, especialmente aquelas que são mais relevantes para a justiça social”, posição por ele defendida, "ou se, alternativamente, deve também se prestar à avaliação moral [...] das normas e valores que guiam as escolhas pessoais dos cidadãos" (p. 102). O segundo caso oferecido ao debate de ideias e posições é o de decidir se a métrica a ser adotada por uma teoria da justiça deve ser a da avaliação normativa da justiça social com base em um "enfoque das capacidades", como defendem A. Sen e M. Nussbaum, ou com base em recursos institucionais (os 'bens primários' de Rawls), tal como ele abraça. 
Por fim, retoma a crítica de Sen de que a teoria rawlsiana da justiça constituiria um "institucionalismo transcendental" - ou uma "idealização excessiva" - em busca de instituições ou de uma sociedade "perfeitamente justas" para demonstrar que o que essa teoria busca é muito mais "justificar princípios para uma sociedade justa” (p. 125) no âmbito de uma "teoria ideal" - em contraposição a uma "teoria não ideal”. Embora seu argumento, que é também metodológico, esteja apenas indicado, Vita aponta para a necessidade de se recorrer, diante de injustiças que sejam sistêmicas, a uma concepção ideal de justiça social, de modo a tornar $\mathrm{a}(\mathrm{o})$ teórica (o) capaz de avaliar as injustiças existentes e de especificar um ideal político praticável, oferecendo orientações claras para a ação política - em um movimento que permitiria ainda conectar certa filosofia política à política prática.

O terceiro artigo, de Ricardo Silva, advoga um modo distinto de fazer teoria política, compromissado com a reconstrução histórica de pensadoras(es), fenômenos e contextos sociopolíticos e com a abordagem metodológica do contextualismo linguístico da Escola de Cambridge, em particular na versão de Q. Skinner. Para tratar essa posição, Silva procede a uma reconstrução da trajetória intelectual de seu maior expoente, Q. Skinner, para ele um autor notavelmente importante para a atual inflexão histórica da teoria política, com o objetivo de mostrar como sua posição historicista "contextualista radical" vem mudando ao longo das últimas décadas, em favor de uma maior permeabilidade com a teoria política normativa. Assim, na primeira seção, procura mostrar que em seus primeiros escritos - de cunho mais metodológico e voltados para uma tentativa de diferenciar-se da "metafísica compreensiva" que predominara na teoria política até então -, Skinner prescrevia "clara distinção entre os campos disciplinares da história do pensamento político e da teoria política contemporânea” (p. 138), 
explorando tanto os argumentos utilizados por Skinner para sustentar essa posição quanto algumas de suas respostas aos críticos à época.

Em seguida, passa a tratar os movimentos skinnerianos nas décadas de 1970 e 1980, procurando mostrar por quais caminhos o pensador se afasta do rígido quadro inicial por ele traçado, movendo-se na direção de um "progressivo afastamento das regras mais restritivas ao intercâmbio entre história [do pensamento político] e teoria política” (p. 151) que supera, até certo ponto, a metodologia. Para tanto, reconstrói a trajetória intelectual skinneriana na direção de compatibilizar teoria política normativa com história do pensamento político, apontando como o autor mobilizaria, primeiro, metáforas arqueológicas - como "escavações" ou "tesouros" - para aproximar a história de ideias situadas em contextos passados - por exemplo a da liberdade neorromana - da teoria política contemporânea e, mais recentemente, a noção de genealogia, a qual permitiria ao teórico político manter um compromisso firme com a história ao mesmo tempo em que o capacita a iluminar com maior eficácia “os aspectos de continuidade, conflito e contingência na história da teoria política” (p. 165), caracterizando assim uma espécie de virada normativa na obra de Skinner.

A contribuição seguinte, formulada por Flávia Biroli, propõe que a teoria política deve ser capaz de abrigar de maneira respeitosa e situada, entre seus muitos "fazeres", também a teoria política de matriz feminista, ela própria internamente plural e diversificada. Sua análise parte da questão do que pensamos estar fazendo quando praticamos a teoria política, proposta por Vincent (2004), para concluir, entre outras coisas, que "a teoria política é teoria de gênero" (p. 177), razão pela qual seus modos de operação precisam ser problematizados e revistos. Assumindo a normatividade de todo exercício de teorização, Biroli se engaja na tarefa de mostrar quais seriam os objetos e fundamentos 
deste tipo de teoria política: teorias feministas diriam respeito a instituições, estruturas e relações cotidianas de poder inseridas numa moldura genérica que engloba política, democracia e justiça, definem-se a partir das posições das mulheres, isto é, de uma perspectiva de gênero - o que não significa afirmar que tenha de ser praticada exclusivamente por mulheres -, em diálogo com as lutas de movimentos sociais organizados, ocupam-se dos sentidos e limites da política e situam-se no entrecruzamento entre normatividade e empiria.

Partindo das cinco concepções de teoria política que teriam demarcado o terreno e a natureza da disciplina propostas por Vincent (2004), Biroli questiona a ausência de críticas, autoras e teorias da justiça feministas nesta reconstrução bem como a utilidade desta distinção quando se assume como foco para pensar a teoria política a perspectiva de gênero. Procura argumentar que os acréscimos trazidos pelas(os) feministas, centrados na inclusão e reversão da invisibilidade do gênero, teriam permitido à teoria política feminista avançar no sentido do atual "deslocamento" do binarismo de gênero que, por meio de seu enquadramento genealógico, permitiria mostrar que a produção de conhecimento é parte da dinâmica de produção do gênero e das identidades. Deste modo, em virtude do caráter masculino e androcêntrico de referências e pressupostos que informam as abordagens teóricas predominantes - conferindo viés de gênero às "realidades" que emergem em estudos empíricos, dado que naturalizam hierarquias e formas de concentração do poder -, urge colocar em xeque a distinção entre normativo e empírico promovida pela ciência [masculina], recolocando os termos sob bases novas.

Por fim, por meio do debate em torno da dicotomia público-privado - que, para a autora, evidencia o quanto a exclusão de gênero organiza as relações nas esferas pública e privada, incidindo sobre a configuração interna e as 
fronteiras da política -, Biroli aborda, na terceira seção, a difícil questão da interseccionalidade na produção de "circuitos da subjugação do conhecimento", que produziria exclusões ancoradas não só em invisibilizações de gênero, mas também de experiências tidas socialmente como subalternas e/ou desqualificadas, razão pela qual é preciso jamais perder de vista as conexões entre experiências, sujeitos e produção de conhecimento, já que "diferentes dimensões do empírico se transformam em problemas teóricos, dependendo de quais relações e sujeitos são considerados e praticam teoria política." (p. 205).

Rúrion Soares Melo participa do debate com uma reflexão que também tem como foco a divisão entre teorias empíricas e normativas da política, mas aborda problemática diferente: procura sustentar que a adoção do método reconstrutivo pela teoria política tanto poderia auxiliar na superação da dicotomia hoje existente entre teorias empíricas e normativas quanto permitiria uma construção aberta, inacabada, de conceitos políticos, sem descuidar de seus contextos históricos e sociais. Com tais objetivos em mente, o autor procura argumentar em favor de uma superação da dicotomia "real" ou "ideal" como base para se pensar a teoria política, buscando sustentar a ideia de que a teoria política "deve refletir sobre seu próprio procedimento de fundamentação, assumindo um papel complementar e reciprocamente constitutivo com a pesquisa social", de modo a não só enriquecer conceitualmente os estudos empíricos mas também permitir que a teoria teste e renove a própria "fundamentação de seus conceitos e categorias tendo em vista as experiências, conflitos e processos diante dos quais a cada vez se vê confrontada." (p. 212).

Para aprofundar seu diagnóstico e justificar suas posições, Melo procura avaliar, na primeira parte do artigo, o lugar da teoria crítica habermasiana na tipologia oferecida por Vincent (2004) e argumenta que pouca atenção é 
dispensada pelo autor à peculiaridade do método reconstrutivo proposto pelo filósofo social alemão - que Vincent reduziria ao fundamento dialógico, ignorando o papel que o contexto histórico e social nele desempenham - para a atividade de teorização política, o qual permitiria à reflexão teórica manter-se aberta aos contextos sociais e seus desafios. Para tanto, expõe os pressupostos da reconstrução assim concebida para, depois, abordar seus limites e potenciais e sustentar a complementaridade entre pesquisa social e reflexão normativa, afirmando que o projeto de uma pesquisa social empírica - apesar de ter sido abandonado por Habermas nos anos 1990 - contribui de modo imanente para a gênese dos conceitos políticos. Por fim, na segunda parte, mostra como a integração entre empiria e normatividade por ele defendida estaria sendo construída em pesquisas atuais realizadas aqui e alhures e informadas por contextos empíricos particulares - dedicadas a pensar as "lutas por reconhecimento" e de que modo ela permitiria fazer avançar o empreendimento teórico, testando, a partir de casos empíricos bem diagnosticados, os potenciais explicativos e críticos das teorias.

A última contribuição do dossiê provém da reflexão feita por Renato Perissinotto e José Szwako a respeito da relevância das ideias tanto para a definição de determinações objetivas que constrangem atrizes e atores no mundo social, gerando problemas políticos, quanto para a produção de diagnósticos adequados ao tempo presente. Para tratar tais ideias, os autores se debruçam, primeiro, sobre uma discussão a respeito do papel da ideias em três autores clássicos, Marx, Weber e Tocqueville, com o objetivo de mostrar que suas teorizações, embora considerassem os constrangimentos externos às ações humanas como limitadores, preservavam espaço significativo para as escolhas das(os) atrizes e atores sociais, baseavam-se em algum diagnóstico a respeito dos processos históricos e faziam prescrições para 
as crises que localizavam - caracterizando o que S. Wolin (1969) denominou "vocação" para a teoria política. Com base numa releitura provocativa e original de Wolin, os autores propõem que a leitora e o leitor considerem a viabilidade de se pensar os movimentos sociais - na medida em que são produtores de ideias e, simultaneamente, de ativismo político - como "teóricos políticos coletivos" (ou "autores em ação").

Para argumentar em favor dessa posição, procedem, na segunda seção, a um debate dos avanços promovidos pela chamada virada ideacional a partir dos anos 1990, mostrando que, apesar dos avanços por ela trazidos para a compreensão do papel das ideias na vida política, tal abordagem teria, em sua ânsia de comprovar as proposições causais da teoria ideacional, se deixado contaminar pelo cientificismo, enveredado no caminho de uma hipertrofia metodológica incapaz de lidar com a dimensão normativa da política. Para mostrar que é possível escapar a essa armadilha, os autores discutem, com base em uma análise de duas políticas de gênero propostas por coletivos feministas no Paraguai, a ideia de que os movimentos sociais conjugam atividades cognitivas de relevo, na medida em que elaboram uma crítica sistemática à sociedade e ao sistema político paraguaios e formulam propostas concretas para sua supressão ou superação dos problemas enfrentados, o que os leva a "caracterizar os movimentos sociais [...] não apenas como "portadores de ideias' razoavelmente eficazes (como sugere a literatura da virada ideacional), mas também como teóricos políticos (nos termos de Wolin).” (p. 246) que têm como um de seus traços o caráter coletivo de suas formulações.

Esperamos assim que, com esse rol de opções e posições devidamente justificadas e fundamentadas que se oferece por meio deste conjunto de textos, a leitora e o leitor possam chegar a uma conclusão informada a respeito da multiplicidade de possíveis modos e "fazeres" da teoria política na 
contemporaneidade, sem contudo abrir mão de defender uma ou outra visão a respeito, a partir de argumentos consistentes, como os que nos proporcionaram as(os) autoras(es) dos artigos que compõem este dossiê. Gostaríamos de deixar registrado ainda nosso agradecimento às(aos) pareceristas desta edição de Lua Nova, cujo trabalho sério, criterioso e voluntário merece louvor e reconhecimento.

\section{Raquel Kritsch}

é Doutora pela Universidade de São Paulo e ProfessoraPesquisadora do Departamento e Programa de Mestrado em Ciências Sociais da Universidade Estadual de Londrina (UEL).

\section{Raissa W. Ventura}

é Doutoranda em Ciência Política pela Universidade de São Paulo (USP).

\section{Bibliografia}

ALMEIDA, D. R. 2014. Representação como processo: a relação Estado/ sociedade na teoria política contemporânea. Revista de Sociologia e Política, v. 22, n. 50, pp. 175-199.

ARAÚJO, C. R. R. 2013. A forma da república: da constituição mista ao Estado. São Paulo: Martins Fontes, 2013.

ARAÚJO, C.; ASSUMPÇÃO, S. R. 2010. Teoria política no Brasil hoje.

In: MARTINS, C. B.; LESSA, R. (orgs.). Horizontes das ciências sociais no Brasil: ciência política. São Paulo: Anpocs, pp. 51-85.

ARAÚJO, C.; VITA, A.; LAVALLE, A. G. (orgs.). 2015. O papel da teoria política contemporânea: justiça, constituição, democracia e representação. São Paulo: Alameda Editorial.

AVRITZER, L. 1994. Sociedade civil e democratização. Belo Horizonte:

Del Rey.

BALL, T. 1995. Reappraising political theory: revisionist studies in the history of political thought. Oxford: Oxford University Press. 2004. Aonde vai a teoria política? Revista de Sociologia e Política, v. 23, pp. 9-22. 
BALLESTRIN, L. M. A. 2017. Feminismos subalternos. Revista Estudos Feministas, v. 25, n. 3, pp. 1035-1054.

BARRY, B. 1998. Political theory, old and new. In: GOODIN, R. E.; KLINGEMANN, H.-D. (eds.). A new handbook of political science. Oxford: Oxford University Press, pp. 531-548.

BEITZ, C. R. 1983. Cosmopolitan ideals and national sentiment. The Journal of Philosophy, v. 80, n. 10, pp. 591-600.

BENHABIB, S. 2006. Another cosmopolitanism. Oxford: Oxford University Press.

BERLIN, I. 2002. Ainda existe a teoria política? In: HARDY, H.;

HAUSHEER, R. (orgs.). Isaiah Berlin: estudos sobre a humanidade. São Paulo: Companhia das Letras, pp. 99-130.

BEYME, K. 1998. Political theory: empirical political theory. In: GOODIN, R. E.; KLINGEMANN, H.-D. (eds.). A new handbook of political science. Oxford: Oxford University Press, pp. 519-530.

BHABHA, H. K. 2002. O local da cultura. São Paulo: Edusp.

BIANCHI, A. 2008. O laboratório de Gramsci: filosofia, história e política. São Paulo: Alameda.

BIROLI, F.; MIGUEL, L. F. 2012. Teoria politica e feminismo: abordagens brasileiras. Vinhedo: Horizonte.

BIROLI, F. 2013. Autonomia e desigualdades de gênero: contribuições do feminismo para a crítica democrática. Vinhedo: Horizonte.

BOGEN, J. 2017. Theory and observation in science. In: ZALTA, E. N. (ed.) The Stanford encyclopedia of philosophy. Stanford: Stanford University Press. Disponível em: <https://goo.gl/dgjtzf>. Acesso em: 24 nov. 2017.

BRANCO, P. H. V. B. C. 2011. Secularização inacabada: política e direito em Carl Schmitt. 1. ed. Curitiba: Appris.

BROCK, G. 2009. Global justice: a cosmopolitan account. Oxford: Oxford University Press.

BROWN, C. 2000. The borders of (international) political theory. In: O'SUlLIVAN, N. (ed.). Political theory in transition. London: Routledge, pp. 190-208.

BROWN, W. 2006. Power after Foucault. In: GOODIN, R. E. (ed.). The Oxford handbook of political theory. Oxford: Oxford University Press, pp. 65-84.

BUTLER, J.; LACLAU, E.; ŽIŽEK, S. 2000. Contingency, hegemony, universality: contemporary dialogues on the left. Rio de Janeiro: Verso.

CARVALHO, B. S. 2008. A escolha racional como teoria social e politica: uma interpretação crítica. Rio de Janeiro: Topbooks. 
CLARK, B. 1979. Eccentrically contested concepts. British Journal of Political Science, v. 9, n. 1, pp. 122-126.

CODATO, A.; PERISSINOTTO, R. M. 2011. Marxismo como ciência social. Curitiba: UFPR.

COHN, G. 2003. Crítica e resignação: Max Weber e a teoria social. São Paulo: Martins Fontes.

COLLINS, P. H. 1986. Learning from the outsider within: the sociological significance of black feminist thought. Social problems, v. 33, n. 6 , pp. 14-32.

COSTA, S. 2006. Dois Atlânticos - Teoria social, anti-racismo, cosmopolitismo. Belo Horizonte: UFMG.

CYFER, I. 2015. Afinal, o que é uma mulher? Simone de Beauvoir e a "questão do sujeito" na teoria crítica feminista. Lua Nova, v. 2, n. 94, pp. 41-77.

EISENBERG, J.; POGREBINSCHI, T. 2002. Pragmatismo, direito e política. Novos Estudos CEBRAP, n. 62, pp. 107-121.

FERES JUNIOR, J. 2000. Aprendendo com os erros dos outros: o que a história da ciência política americana tem para nos contar. Revista de Sociologia e Política, n. 15, pp. 97-110. 2005. De Cambridge para o mundo, historicamente: revendo a contribuição metodológica de Quentin Skinner. Dados, v. 48, n. 3, pp. 655-680.

FERES JÚNIOR, J.; JASMIN, M. (orgs.). 2007. História dos conceitos: diálogos transatlânticos. São Paulo: Loyola.

FERREIRA, B. 2004. O risco do político: crítica ao liberalismo e teoria política no pensamento de Carl Schmitt. 1. ed. Belo Horizonte: UFMG.

FOUCAULT, M. 2005. Em defesa da sociedade: curso no Collège de France (1975-1976). São Paulo: Martins Fontes.

FRANK, J.; TAMBORNINO, J. (eds.). 2000. Vocations of political theory. Minneapolis: University of Minnesota Press.

FRASER, N et. al. 2014. Transnationalizing the public sphere. Cambridge: Polity Press.

FRAZER, E. 2008. Political theory and the boundaries of politics. In: LEOPOLD, D.; STEARS, M. (eds.). Political theory: methods and approaches. Oxford: Oxford University Press.

GALLIE, W. B. 1955. Essentially contested concepts. New Series, v. 56, pp. 167-198.

GRANT, R. W. 2002. Political theory, political science, and politics. Political Theory, v. 30, n. 4, pp. 577-595. 
GRAY, J. N. 1977. On the contestability of social and political concepts.

Political Theory, v. 5, n. 3, pp. 331-348.

GUNNELL, J. G. 1987. Political theory: tradition and interpretation. New York: University Press of America. 1993. The descent of political theory: the genealogy of an American vocation. Chicago: Chicago University Press. 2011. Political theory and social science - cutting against the grain. New York: Palgrave Macmillan.

HABERMAS, J. 2000. Discurso filosófico da modernidade. São Paulo: Martins Fontes. 2001. A constelação pós-nacional: ensaios políticos. São Paulo: Littera Mundi.

HALL, S. 1992. The west and the rest: discourse and power. In: HALL, S.; GIEBEN, B. (eds.). Formations of Modernity. Cambridge: Polity Press, pp. 275-320.

HANSON, N. R. 1958. Patterns of discovery: an inquiry into the conceptual foundation of science. Cambridge: Cambridge University Press.

HARAWAY, D. 1988. Situated knowledges: the science question in feminism and the privilege of partial perspective. Feminist studies, v. 14, n. 3, pp. 575-599.

HART, H. L. A. 1961. The concept of law. Oxford: Clarendon.

JASMIN, M. G. 1997. Alexis de Tocqueville: a historiografia como ciência da política. Rio de Janeiro: Access.

JASMIN, M. G.; FERES JUNIOR, J. (orgs.). 2006. História dos conceitos: debates e perspectivas. Rio de Janeiro: PUC.

KALDOR, M. 2003. The idea of global civil society. International affairs, v. 79, n. 3, pp. 583-593.

KECK, M.; SIKKINK, K. 1998. Activists beyond borders: transnational activist networks in international politics. Ithaca, NY: Cornell University Press.

KERSTENETZKY, C. L. 2012. O estado do bem-estar social na idade da razãoa reinvenção do estado social no mundo contemporâneo. Rio de Janeiro: Alta Books.

KOERNER, A. 2012. A história do direito como recurso e objetivo de pesquisa. Diálogos, v. 16, n. 2, pp. 627-662. . 2015. A Ordem Constitucional da República: uma análise política da jurisdição constitucional no Brasil (1889-1926). 513 p. Tese (Livre-docência em Política e Direito) - Departamento de Ciência Política, Universidade Estadual de Campinas, Campinas, 2015.

LACERDA, G. B.; PERISSINOTTO, R.; SZWAKO, J. E. L. (orgs.). 2016. Curso livre de teoria politica: normatividade e empiria. Curitiba: Appris. 
LASLETT, P. 1962[1956]. Introduction. In: LASLETT, P.; RUNCIMAN, W. G. (eds.). Philosophy, politics and society. Oxford: Basil Blackwell, pp. vii-x. LATOUR, B. 2005. Reassembling the social: an introduction to actor-networktheory. Oxford: Oxford University Press.

LAVALLE, A. G. 2004. Vida pública e identidade nacional-Leituras Brasileiras. Porto Alegre: Globo.

LAVALLE, A. G.; VERA, E. I. 2011. A trama da crítica democrática: da participação à representação e à accountability. Lua nova, n. 84, pp. 353-364.

LEOPOLD, D.; STEARS, M. (eds.). 2008. Political theory: methods and approaches. Oxford: Oxford University Press.

LESSA, R. 1998. Por que rir da Filosofia Política?: abertura. Revista Brasileira de Ciências Sociais, v. 13, n. 36, s/p.

LIST, C.; VALENTINI, L. 2016. The methodology of political theory. In: CAPPELEN, H.; GENDLER, T. S.; HAWTHORNE, J. The Oxford handbook of philosophical methodology. Oxford: Oxford University Press, pp. 525-553.

LÜCHMANN, L. H. H. 2007. A representação no interior das experiências de participação. Lua Nova, n. 70, pp. 139-170.

52 LYNCH, C. E. C. 2014. Da monarquia à oligarquia: história institucional e pensamento político brasileiro (1822-1930). São Paulo: Alameda. 2016. Cartografia do pensamento político brasileiro: conceito, história, abordagens. Revista Brasileira de Ciência Política, n. 19, pp. 75-119.

MATOS, M. 2013. Feminismo e teorias da justiça. In: AVRITZER, L.; et. al. (orgs.). Dimensões políticas da justiça. Rio de Janeiro: Civilização Brasileira, pp. 141-155.

MELO, R. S. 2011. O uso público da razão: pluralismo e democracia em Jürgen Habermas. São Paulo: Loyola.

MENDES, C. H. 2013. Constitutional courts and deliberative democracy. 1. ed. Oxford: Oxford University Press.

MENDONÇA, D. 2003. A noção de antagonismo na ciência política contemporânea: uma análise a partir da perspectiva da teoria do discurso. Revista de Sociologia e Política, n. 20, pp. 135-145.

MENDONÇA, D.; RODRIGUES, L. P. (orgs.). 2008. Pós-estruturalismo e teoria do discurso: em torno de Ernesto Laclau. Porto Alegre: PUC.

MENDONÇA, R. F. 2013. Teorias críticas e pragmatismo: a contribuição de G. H. Mead para as renovações da escola de Frankfurt. Lua Nova, São Paulo, n. 90, pp. 367-403. 
MIGNOLO, W. D. 2008. Desobediência epistêmica: a opção descolonial e o significado de Identidade em política. Cadernos de Letras da UFF, n. 34, pp. 287-324.

MIGUEL, L. F. 2003. Representação política em 3-D: elementos para uma teoria ampliada da representação política. Revista Brasileira de Ciências Sociais, v. 18, n. 51, pp. 123-140.

2005. Teoria da democracia atual: esboço de mapeamento. Revista Brasileira de Informação Bibliográfica em Ciências Sociais, v. 59, pp. 5-42. 2011. Representação democrática: autonomia e interesse ou identidade e advocacy. Lua Nova, n. 84, pp. 353-364.

MOHANTY, C. T. 1988. Under western eyes: feminist scholarship and colonial discourses. Feminist review, v. 30, n. 1, pp. 61-88.

MOUFFE, C. 1995. Feminism, citizenship, and radical democratic politics. In: NICHOLSON, L.; SEIDMAN, S. (eds.). Social postmodernism: Beyond identity politics. Cambridge: Cambridge University Press, pp. 315-331.

NELSON, J. S. (ed.). 1983. What should political theory be now? Albany: State University of New York Press.

NEVES, M. 2012. Transconstitucionalismo. São Paulo: Martins Fontes. OSTRENSKY, E. 2006. As revoluções do poder. São Paulo: Alameda.

PAREKH, B. 1998. Political theory: traditions in political philosophy. In: GOODIN, R. E; KLINGEMANN, H.-D. (eds.). A new handbook of political science. Oxford: Oxford University Press, pp. 503-518.

PHILLIPS, A. 1997. Dealing with difference: a politics of ideas or a politics of presence? In: GOODIN, R. E.; PETTIT, P. (eds.) Contemporary political philosophy: an anthology. Oxford: Wiley-Blackwell, pp. 174-184.

PINTO, C. R. 1994. Participação (Representação?) política da mulher no Brasil: limites e perspectivas. In: SAFFIOTI, H.; MUÑOS-VARGAS, M. (orgs.). Mulher brasileira é assim. Rio de Janeiro: Rosa dos Ventos, pp. 195-230.

PINTO, C. R. 2017. É possível falar de um discurso feminista no século XXI. In: MENDONÇA, D.; RODRIGUES, L. P.; LINHARES, B. (orgs.). Ernesto Laclau e seu legado transdisciplinar. São Paulo: Intermeios, pp. 85-107.

PLAMENATZ, J. 1960. The use of political theory. Political Studies, v. 8, n. 1, pp. 37-47.

POGGE, T. 2001. Priorities of global justice. Metaphilosophy, v. 32, n. 1/2, pp. 6-24.

QUINE, W. V. O. 2011. De um ponto de vista lógico. São Paulo: Unesp. 
QUIRINO, C. G.; BRANDÃO, G. M.; VOUGA, C. (orgs.). 1998. Clássicos do pensamento político. São Paulo: Edusp.

RAWLS, J. 2003. Justice as fairness: a restatement. Cambridge, MA: Harvard University Press. . 2008. Uma teoria da justiça. São Paulo: Martins Fontes. 2011. O liberalismo político. São Paulo: Martins Fontes.

REGO, W. L.; PINZANI, A. 2013. Vozes do Bolsa-Família: autonomia, dinheiro e cidadania. São Paulo: Unesp.

REIS, B. W. 1990. A questão da racionalidade na teoria da ação comunicativa: um diálogo com a abordagem da 'escolha racional. Dissertação (Mestrado em Ciência Política) - Instituto Universitário de Pesquisas do Rio de Janeiro, Rio de Janeiro.

SEMBOU, E. (ed.). 2013. Political theory: the state of the discipline. Newcastle: Cambridge Scholars Publishing.

SHAPIRO, I. 2002. Problems, methods, and theories in the study of politics, or what's wrong with political science and what to do about it. Political theory, v. 30, n. 4, pp. 596-619.

SHAPIRO, I.; GREEN, D. 1994. Pathologies of rational choice theory: a critique of applications in political science. New Haven: Yale University Press.

SILVA, R. 2008a. Identidades da teoria política: entre a ciência, a normatividade e a história. Pensamento Plural, v. 1, n. 3, pp. 9-22. . 2008b. Liberdade e lei no neo-republicanismo de Skinner e Pettit. Lua Nova, n. 74, pp. 151-194. 2010. O contextualismo linguístico na história do pensamento político: Quentin Skinner e o debate metodológico contemporâneo. Dados, v. 53, n. 2, pp. 299-335. 2011. Republicanismo neo-romano e democracia contestatória. Revista de Sociologia e Política, v. 19, n. 39, pp. 35-51. . 2015. Visões da liberdade: republicanismo e liberalismo no debate teórico contemporâneo. Lua Nova, n. 94, pp. 181-215.

SIMMONS, A. J. 2010. Ideal and Nonideal Theory. Philosophy Eं Public Affairs, v. 38, n. 1, pp. 5-36.

SPIVAK, G. C. 2010. Pode o subalterno falar? Belo Horizonte: UFMG. STEMPLOWSKA, Z.; SWIFT, A. 2012. Ideal and non-ideal theory. In: ESTLUND, D. (ed.). The Oxford handbook of political philosophy. Oxford: Oxford University Press, p. 373-392.

STRAUSS, L. 1957. What is political philosophy? The Journal of Politics, v. 19 , n. 3, pp. 343-368

VALENTINI, L. 2012. Ideal vs. Non-ideal theory: a conceptual map. Philosophy Compass, v. 7, n. 9, pp. 654-664. 
VINCENT, A. 2004. The nature of political theory. Oxford: Oxford University Press.

VITA, A. 2007. A justiça igualitária e seus críticos. 2. ed. São Paulo: Martins Fontes. 2008. O liberalismo igualitário: sociedade democrática e justiça internacional. São Paulo: Martins Fontes.

WALDRON, J. 2016. Political political theory: essays on institutions. Cambridge, MA: Harvard University Press.

WARREN, M. E. 1989. What is political theory/philosophy? PS: Political Science E Politics, v. 22, n. 3, pp. 606-612.

WEBER, M. 1972. A Ciência como Vocação. In: WEBER, M. Ciência e política: duas vocações. São Paulo: Cultrix.

WHITE, S. K.; MOON, J. D. (eds.). 2004. What is political theory? London: Sage.

WOLIN, S. S. 1960. Politics and vision. Continuity and innovation in western political thought. Boston: Little Brown. . 1969. Political theory as a vocation. American Political Science Review, v. 63, n. 4, pp. 1062-1082. . 2000. Political theory: from vocation to invocation. In:

FRANK, J.; TAMBORNINO, J (eds.). Vocations of political theory. Minneapolis: University of Minnesota Press, pp. 3-22.

YOUNG, I. 1998. Political theory: an overview. In: GOODIN, R. E.;

KLINGEMANN, H.-D. A new handbook of political science. Oxford:

Oxford University Press, pp. 479-502. 2011. Responsibility for justice. Oxford: Oxford University Press. 


\section{TEORIA POLÍTICA, PLURALIDADE E PLURALISMO: UM DEBATE}

\section{RAQUEL KRITSCH}

\section{RAISSA W. VENTURA}

Resumo: Esta introdução ao dossiê Teoria Política Contemporânea procura abordar, por meio de reflexão a respeito dos temas da pluralidade e do pluralismo, o diagnóstico de que a teoria política conta atualmente com multiplicidade de vocabulários e "fazeres". Para tanto, apresentamos as cinco concepções de teoria política - normativa clássica, institucional, histórica, empírica e ideológica - localizadas por A. Vincent em 2004 e que teriam demarcado o terreno da disciplina bem como sua prática de meados do século XIX até nossos dias. Em seguida, procuramos justificar em dois passos de que modo a pluralidade e o pluralismo epistemológico constituem parte incontornável da produção de conhecimento levada a cabo neste campo. Concluímos que, dada sua atual condição de parcialidade, a produção de conhecimento na teoria política poderia ser mais bem exercida se fosse compreendida e tomada como empreendimento coletivo inacabado. Por fim, procedemos à breve apresentação dos artigos que compõem o dossiê.

Palavras-chave: Teoria Política Contemporânea; Pluralidade; Pluralismo.

\section{CONTEMPORARY POLITICAL THEORY, PLURALITY AND PLURALISM: A DISCUSSION}

Abstract: In this introduction to the Contemporary Political Theory dossier, we seek, through a reflection on the issues of plurality and pluralism, to address the fact that nowadays political theory presents a multiplicity of vocabularies and practices. In this manner, we introduced five political theory conceptions - classical normative, institutional, historical, empirical and ideological - which were 
reconstructed by A. Vincent in 2004. These conceptions would have marked out the terrain of the discipline as well as its practice from the middle of the nineteenth century to the present. Next, we seek to justify, in two steps, how plurality and epistemological pluralism are an inescapable part of knowledge production carried out in this field. We conclude that, given the partiality permeating it, the production of knowledge in political theory would achieve better results if it were understood and taken as an open-ended collective enterprise. Finally, we briefly present the articles that make up the dossier.

Keywords: Contemporary Political Theory; Plurality; Pluralism.

Recebido: 15/09/2017Ａprovado: 14/11/2017 